UDC 37.13:373.3(091)[(410)+(430)]

DOI https://doi.org/10.32841/2409-1154.2019.42.3.17

\author{
Polishchuk L. P., \\ Associate Professor of English Philology and Translation Department, \\ of the Zhytomyr Ivan Franko State University
}

\author{
Pushkar T. M., \\ Associate Professor of English Philology and Translation Department \\ of the Zhytomyr Ivan Franko State University
}

\title{
CURRENT TRENDS IN THE PREPARATION OF FUTURE PHILOLOGISTS-TRANSLATORS
}

\begin{abstract}
Summary. The article highlights the current trends in the training of future philologists-translators, namely the combination of traditions and innovations. An innovative way of social development can only be secured if a generation of thinking and acting people is formed. Considerable attention is paid to the person's overall development, his communicative abilities, independence in making decisions, criticality and culture of thinking, development of information and social skills. The need to improve these issues is conditioned by the state of modern society, because in the context of constant expansion and deepening of the spheres of intercultural communication in the modern world, and in particular in Ukraine, there is a need to reform translation education. The demand of the Ukrainian university in the formation of intellectual and creative philologist-translator is growing. Successful professional realization of future translators depends on their professional training, which is aimed at the developing of their communicative competence and provides not only the mastering of the language as the means of communication, training, self-education and ensuring a free, normativecorrect and functionally-adequate command of all types of language skills level, close to the level of the native speaker, but also allows them, after graduation, to carry out all the functionalities and responsibilities. The professional training of potential translators at the university is carried out within the framework of the course of translation theory and practice that means the set of knowledge, skills and abilities which allow the translator to solve their professional tasks successfully. Current requirements for the professional training of future philologists-translators should also take into account the recommendations of the European Council, which clearly outline the task of forming specialists who will be capable to compete in today's employment market.
\end{abstract}

Key words: training, philologists-translators, communicative competence, current requirements.

Formulation of the problem and justification of its relevance. The integration of all aspects of our country's life into the European space not only opens up a new field of professional activity for translators, but also places them in conditions of fierce competition, which necessitates the definition of the effective ways of forming the professional qualities of future translators.

Analysis of recent research and publications. The analysis of the scientific literature gave us the opportunity to systematize the experience of domestic and foreign scientists in the following areas: qualification directions of training translators (N. Gavrilenko, V. Karaban, A. Kozak, S. Kolomiets, R. Kriss, E. Pim, L. Chernovaty); organization of vocational training of translators in higher education institutions of Ukraine and abroad (E. Besedina, K. Claudy, O. Kovyazina, A. Kozak, V. Radchuk, B. Rubrecht, R. Tinsley); pedagogical conditions of the formation of translator's professional competence (L. Barkhudarov, V. Ilyin, A. Kozak, V. Komissarov, L. Latyshev, R. Minyar-Beloruchev, G. Miram, N. Mironova, L. Mitina, S. Nikolaeva, Yu. Passov, Z. Podruchna, J. Retzker, N. Sobol, L. Tarkhova, A. Fedorov, I. Khaleeva, M. Zwilling, $\mathrm{O}$. Cherednichenko); the use of interactive technologies in the training of translators (A. Ahayan, T. Humennikova, N. Ivanitskaya, K. Karpov, L. Kartashova, S. Kolomiets, Y. Kolos, V. Terekhova, A. Yankovets).

Formulation of the purpose and objectives of the article. The reform of the professional training system of future philologists cannot be imagined without such a phenomena as integration, the Bologna process, modernization, which are an external factor in contemporary educational changes. By becoming a full participant in the Bologna Process, Ukraine coordinated it with the priorities of higher education development and carries out modernization of educational activities in the context of European guidelines. According to the National Doctrine of Educational Development of Ukraine in the 21st Century (2002), these include modernization of the content, forms and methods of teaching, development and implementation of state standards of pedagogical education. More specifically on these changes, the Action Program for the Implementation of the Bologna Declaration in Higher Education and Science of Ukraine (2004) and the Law of Ukraine "On Higher Education" (2006), which provides fundamental professional, psychological and practical training for future translators.

The relevance of the presented research is conditioned by the need to modernize the system of professional training of future translators, as well as the existing contradictions between: the need of society for highly qualified philologists, capable of functioning in the modern labor market, and insufficient level of their preparation; the need to modernize the content of professional training of future philologists and ways of their implementation; the need to introduce a uniform system of standards for the professional training and activity of the philologist-translator and the ways of their implementation.

The purpose of the article is to identify the most important aspects of improving the professional training of future translators, namely the combination of tradition and innovation in training. An innovative way of social development can only be secured if a generation of people who think and act in an innovative way is formed. 
Presenting main material. The main problem of training qualified philologists, who are able to satisfy the requirements of the modern labor market as effectively as possible, is the need to combine the knowledge of a foreign language and the ability to fulfil those requirements, which are put forward by the practice of intercultural communication.

The most typical way to master this profession is to move from knowledge to skills and from skills to skills. The main purpose of university training is to close the gap between theoretical and practical knowledge and to be free to orientate in various fields of professional activity. For practical consolidation of theoretical material, it is necessary to distinguish the following approaches in the selection of theoretical material: inductive, deductive and functional. The first one involves the translation of 10-15 texts selected by the teacher during the semester, with subsequent verification, discussion of the results of the work and generalization of recommendations for solving certain translation problems. The deductive approach is based on the thematic development of translation techniques, when the teacher formulates a topic for processing (for example, translating proper names, units, etc.) and then chooses practical tasks. The last of these approaches is to formulate individual translation skills by performing relevant practical tasks [4, p. 95].

Important for the effectiveness of training is the amount of training material that should be as close as possible to the real tasks of a professional philologist. In addition, students must acquire computer typing skills, use of up-to-date software, and search for relevant information online.

Therefore, the main aspect of training multidisciplinary translation philologists is not only the provision of a complex of knowledge, skills and competences (professional competence) of a specialist, but also the need to further study the specifics of translation activities in a particular field.

The American scientist B. Rubbrecht has developed ten concepts that reflect the nature of the educational activities and profession of the philologist-translator: students do not become professional philologists-translators within the walls of the institution, and the student must cultivate the willpower; knowledge of a foreign language is necessary but not sufficient for translation; translation is a part, not the result, of the language learning process; the ultimate goal of translation philologists is to get people to understand their translation; not all practical tasks are of interest to students; all the exercises offered by the teacher should meet the purpose set by him; translation skills require more than understanding the meaning of individual words; a completed translation is never finalized; translation, above all, requires discipline [3].

Another aspect of the vocational training of translators is to familiarize students with the structure and stylistic features of the source and target languages. For example, comparing features of translation of fiction and technical literature, the main task of the translator of fiction is to cover literary images, whereas the technical translator must convey the facts. That is why the translator of technical literature should know the subject of translation and possess the style inherent in this genre [2, p. 102].

That is why the content of the Theory and Practice of Translation course should include both the communication of necessary professional knowledge and the development of translation skills. At the same time, translation skills and goals are the ultimate goal of the translation course, because they ensure the practical professional activity of the translator. Translation skills are created through the use of specially selected training materials. Such materials include translation exercises and study texts.

The development of translators' training programs should be carried out by specialists directly involved in both pedagogical and translation practice. The organization of the educational process and the selection of educational material should be in accordance with the specifics of the translation industry. After a short period of mastering general education, students must choose a field of specialization that meets the needs of the translation services market and their preferences, and continue their education in a defined direction. Of great importance for the effectiveness of training is the amount of training material that should be as close as possible to the real tasks of a professional translator; in this case, we believe that the educational material should be renewed every two years. An important task in the process of forming a translation competence is also to acquire the skills of quick and high-quality translation tasks, computer skills, the ability to use modern software and search for the necessary information on the Internet. A significant requirement of a large number of training programs should be the experience of living, studying or translating practice in the language being taught, as the organization of the practice is one of the necessary elements for the professional development of a future translator.

In our opinion, active integration into the European and world educational environment should contribute to solving the problems of quality control of translatorse education and non-recognition of diplomas of Ukrainian specialists abroad.

On the basis of a thorough analysis of theoretical provisions of teaching translation as a specialty, the state of research of the problem of professional training of future translators, linguistic, translation, psychological and psycholinguistic prerequisites of the content of teaching oral translation determines the concept of their preparation for professional communication in the sphere of economic activity, the way to create a model of professional competency formation of an interpreter points to the problem $b$ construction of pedagogical and methodological technologies. The provisions of psycholinguistics as a methodology are used in the process of teaching interpretation in intercultural communication, aimed at mastering the highest level of translation skills through the formation of interconnection of language and culture, thinking and consciousness (the highest form of development of the future specialist's psyche, manifested in the world map) which leads to the desired result of interpreters training and is achieved through three approaches (subject-energy, cognitive and computational) ethnic), each of which forms a certain professional quality of the translation personality and a number of principles that are implemented in the process of selecting didactic filling of educational programs, in the process of typological and thematic filling of the content of training and for the development of a system of tasks). Structural (bilingual and cultural, personal, subject, translation and strategic competences) and content (knowledge, skills, abilities, abilities) components of the professional competence of the interpreter are determined.

To determine the procedure of control of the level of professional competence of the interpreter in the foreign economic sphere, the generalized results of the teaching of consecutive translation are described, descriptors are proposed for 5 determination of the level of formation of students of the magistracy of professional competence 
of the interpreter. The methodological system of formation of professional competence of the interpreter corresponds to the ultimate goals of training, has a uniform structure of formation of translation skills, abilities and abilities and is built on typical situations of real professional activity and is organized according to the separate stages translation activities (comprehension of the original statement, decision making and implementation of translation). Formation of professional competence of a translator in consecutive translation in foreign economic sphere is realized in stages: preparatory (stage of acquisition of knowledge and formation of special skills of consecutive translation, basic (automation of special skills and formation of special and strategic skills of consecutive translation) and final (development of special and strategic skills of consistent translation in foreign economic sphere). The system of exercises is aimed at the development of a complex of psycholinguistic mechanisms for generating the text of translation and meets the ultimate goals of teaching the translation of philologists who will work in the field of foreign economic activity, and is implemented by the stages of the interpreter's actions. in the phase of making a translation decision, which corresponds to the three stages of learning sequential translation, each contributing to the development of the corresponding element of the triad "language and culture - thinking - consciousness".

To summarize, it should be noted that the specification of translation determines the availability of a translator of a special (background) knowledge and skills necessary for successful professional activity in a particular field. Many researchers have come to the conclusion that the importance of such a component of the professional competence of a narrow profile translator is a subject matter competence or thematic competence, as well as the need for knowledge in the field of future professional activity (subject matter knowledge), declarative knowledge - about the labor market, customer requirements, standards of behavior and relations between the translator and the client, sources of information, translation tools, etc., as well as procedural knowledge [1, p. 173].

Conclusions. The analysis of pedagogical research of domestic scientists showed that the problems of professional training of translators-philologists remain relevant at the present stage of development of education in Ukraine. We can point out that the concept of philological education is based on a competent approach in the training of future specialists. The professional competence of a translator-philologist should be directed to the provision of the following basic functions: written and oral communication in various spheres of public activity; the use of modern methods of collecting and processing information, the use of global information networks, automated search systems, electronic databases, glossaries and directories; conducting scientific research in the field of professional activity.

\section{References:}

1. Gile D. Basic concepts and models for interpreter and translator training. John Benjamins Publishing Company, 2009. P. 119.
2. Miram G.E. Profession: Translator / G.E. Peace. K. : Nika-Center, 1999. Pp. 89-90.

3. Rubrecht Brian G. Knowing Before Learning: Ten concepts students should understand prior to enrolling in a university translation or interpretation class [Access mode] / Brian G. Rubrecht. Translation Journal. 2005. Vol. 9. No. 2. URL : http://translationjournal.net/ journal//32edu.htm.

4. Talanova Zh.P. Pedagogical conditions of formation of professional outlook of the future translator: author. diss. for the sciences. degree of Cand. ped. Sciences: Special. 13.00.04 "Theory and methodology of vocational education" / Zh.P. Talanov. Kirovograd. 2007. p. 56.

Поліщук Л. П., Пушкар Т. М. Сучасні тенденції в підготовці майбутніх перекладачів-філологів

Анотація. У статті розглянуто основні аспекти професійної підготовки майбутніх філологів-перекладачів та визначено ефективні шляхи формування їх професійних якостей. Обгрунтовано необхідність модернізації системи професійної підготовки майбутніх перекладачів та запровадження єдиної системи стандартів цієї підготовки. Визначено найважливіші аспекти вдосконалення професійної підготовки майбутніх перекладачів, а саме поєднання традицій та інновацій у навчанні. Висвітлено концепції, розроблені американським ученим Б. Руббрехтом, які відображають характер навчальної діяльності та професії філолога-перекладача. На підставі систематизації й узагальнення теоретичних надбань вітчизняних і зарубіжних дослідників, а також шляхом порівняльного аналізу наявних перекладацьких програм установлено переваги формування перекладацької компетенції в умовах євроінтеграції: 1) модернізація навчального процесу за рахунок швидкого поповнення словникового запасу; 2) формування навичок двостороннього перекладу текстів певних функціональних стилів; 3) організація самостійної роботи; 4) використання Інтернету як основного засобу модернізації освіти. Описано переваги та недоліки Інтернет-програм, зорієнтованих на різні види перекладацької діяльності. Комп’ютеризація інформаційних технологій стимулює подальший розвиток систем автоматизованого перекладу, що, у свою чергу, призводить до формування нових засад підготовки перекладачів - наочності й автономності. Проаналізовано аспекти підготовки багатодисциплінарних перекладачів-філологів та необхідність подальшого вивчення специфіки перекладацької діяльності в певній галузі. Визначено специфіку перекладацької галузі. 3'ясовано завдання у процесі формування перекладацької компетенції. Досліджено, що важливістю компонента професійної компетентності перекладача вузького профілю є предметна компетенція або тематична компетентність, а також необхідність знань у галузі майбутньої професійної діяльності, декларативні знання про ринок праці, вимоги замовника, стандарти поведінки та відносини між перекладачем та клієнтом, джерела інформації, засоби перекладу тощо, а також процесуальні знання. Зроблено висновки, що проблеми професійної підготовки перекладачів-філологів залишаються актуальними на сучасному етапі розвитку освіти в Україні.

Ключові слова: філолог-перекладач, комунікативна компетентність, сучасні вимоги, професійні знання. 